\title{
Teleporady w opiece nad chorymi na astmę - zalety i ograniczenia
}

\section{Televisits for asthma care - advantages and limitations}

\author{
Katarzyna Górska', Michał Mierzejewski² \\ ${ }^{1}$ Katedra i Klinika Chorób Wewnętrznych, Pneumonologii i Alergologii, Warszawski Uniwersytet Medyczny \\ ${ }^{2}$ Oddział Chorób Płuc i Gruźlicy, Mazowieckie Centrum Leczenia Chorób Płuc i Gruźlicy w Otwocku
}

\begin{abstract}
Streszczenie:
Telemedycynę coraz częściej wykorzystuje się do poprawy wyników zdrowotnych w astmie. Nadal nie zostało ustalone, czy ta forma opieki jest skuteczna, zwłaszcza podczas zaostrzenia, jednak pandemia COVID-19 doprowadziła do rozpowszechnienia telemedycyny. Ma ona niezaprzeczalne zalety, jak np. możliwość objęcia opieką pacjentów w miejscach oddalonych od ośrodków miejskich, o dużym rozproszeniu ludności, pacjentów z utrudnieniami w poruszaniu się; oszczędność czasu i kosztów transportu oraz możliwość zastosowania w czasie ograniczeń epidemicznych. W niniejszym artykule przedstawiono możliwości i cele telemedycyny u chorych z rozpoznaniem astmy, uwzględniając okres zaostrzenia. Zaproponowano podstawowe schematy badania przedmiotowego i podmiotowego, ze szczególnym podkreśleniem oznak pomagających w selekcji pacjentów wymagających oceny stacjonarnej.

\section{Abstract:}

Telemedicine is increasingly used to improve health outcomes in asthma. It is still unclear whether this form of care is effective, especially during an exacerbation, however the COVID-19 pandemic has led to its spread. There are undeniable advantages, such as: taking care of patients in places remote from urban centers, in areas with a large population dispersion, patients with difficulties in moving, saving time and costs of transport, and safety in times of epidemic constraints. In this article, we present the potential possibilities and goals of telemedicine in patients diagnosed with asthma, including acute exacerbation. We propose the basic outline of physical and medical examination, with particular emphasis on the signs supporting the selection of patients requiring stationary assessment.
\end{abstract}

Słowa kluczowe: astma, kontrola astmy, teleporada, telemedycyna, zaostrzenie

Key words: asthma, asthma control, televisit, telemedicine, exacerbation

\section{Astma - definicja i rozpoznawanie}

Astma to jedna $\mathrm{z}$ najczęstszych przewlekłych chorób układu oddechowego. Definiowana jest jako heterogenna choroba zapalna dróg oddechowych, charakteryzująca się występowaniem świstów, krótkiego oddechu, ucisku w klatce piersiowej i kaszlu. Objawy mogą mieć różną intensywność i są zmienne w czasie, co wynika ze zmiennego ograniczenia przepływu w drogach oddechowych. Mimo postępu wiedzy pozwalającego na lepsze zrozumienie mechanizmów choroby, wprowadzenia nowych metod diagnostycznych, a także terapeutycznych właściwe rozpoznanie astmy oraz dobra kontrola choroby wciąż stanowią istotny problem medyczny.

Rozpoznanie astmy w dużym stopniu opiera się na obrazie klinicznym, a ustalone właściwie zwiększa szanse na efektywność leczenia. Prawidłowe postępowanie zmierzające do ustalenia rozpoznania astmy wymaga udokumentowania: 
- objawów klinicznych sugerujących astmę (im więcej objawów typowych dla astmy, tym większe prawdopodobieństwo rozpoznania)

- zmienności przepływu powietrza w drogach oddechowych: wynik spirometrii z próbą rozkurczową lub rejestracja szczytowego przepływu wydechowego (PEF, peak expiratory flow) za pomocą pikflometru.

Długoterminowa opieka nad chorym na astmę wymaga edukacji i opiera się $\mathrm{w}$ głównej mierze na obrazie klinicznym. W celu optymalizacji jej efektów po ustaleniu rozpoznania astmy wskazane są:

- prowadzenie edukacji w zakresie podstaw patomechanizmów choroby i zasad leczenia; wskazanie roli wziewnych glikokortykosteroidów (wGKS)

- ocena czynników ryzyka zaostrzenia i złego przebiegu astmy

- spersonalizowany dobór inhalatora w oparciu o sprawność manualną i intelektualną pacjenta, ale również stopień nasilenia choroby

- zademonstrowanie i przećwiczenie $\mathrm{z}$ pacjentem techniki inhalacji proponowanego leku wziewnego

- przekazanie pacjentowi pisemnego planu przewlekłego leczenia oraz postępowania w przypadku nasilenia objawów (zaostrzenia)

- zaplanowanie wizyty kontrolnej po 1-3 miesiącach w celu oceny odpowiedzi na leczenie.

Realizacja powyższych wytycznych od początku opieki nad chorym zwiększa szanse na prowadzenie dalszej skutecznej opieki na drodze teleporad. Jednak trudności zaczynają się wraz z wystąpieniem zaostrzenia choroby.

Zaostrzenie astmy to sytuacja, w której dochodzi do nasilenia dotychczasowych objawów i pogorszenia funkcji układu oddechowego, wykraczającego poza ich codzienną zmienność dobową i wymagającego zmiany dotychczasowego leczenia. W początkowym okresie zaostrzenia trudno odróżnić napad duszności od zaostrzenia astmy. Napad duszności to przemijający epizod skurczu oskrzeli, bez nasilenia zapalenia w oskrzelach, ustępujący po podaniu leku doraźnego lub samoistnie. Natomiast zaostrzenie astmy jest stanem trwającym dłużej, związanym z nasileniem zapalenia w drogach oddechowych i potrzebą intensyfikacji leczenia przeciwzapalnego. Zdefiniowanie momentu zaostrzenia bywa trudne zarówno dla pacjentów, jak i lekarza. Istnieje kilka terminów, którymi pacjenci opisują zaostrzenie, np.: napad, epizod czy atak astmy.

Rozpoznanie zaostrzenia opiera się przede wszystkim na ocenie nasilenia objawów, czyli duszno- ści, świstów, kaszlu, ucisku w klatce piersiowej i pogorszenia tolerancji wysiłku.

Oceniając chorego z zaostrzeniem astmy, trzeba przeanalizować czynniki, które wpływają na zwiększone ryzyko zgonu. Chorzy z tymi czynnikami wymagają intensywnego leczenia od momentu pojawienia się pierwszych objawów i częściej wymagają leczenia w szpitalu.

Czynniki zwiększające ryzyko zgonu w zaostrzeniu astmy to:

- przebyte wcześniej zaostrzenie zagrażające życiu wymagające intubacji i wentylacji mechanicznej

- hospitalizacja lub wizyta w izbie przyjęć z powodu zaostrzenia astmy w ostatnim roku

- aktualne lub niedawno zakończone leczenie doustnymi GKS

- niestosowanie wGKS

- nadużywanie krótko działających $\beta_{2}$-mimetyków (SABA, short-acting $\beta_{2}$-agonists), zwłaszcza $>1$ opakowania w ciągu miesiąca

- choroby psychiczne lub trudności psychologiczne w wywiadach

- zła współpraca, niestosowanie się do planu leczenia astmy

- współistnienie astmy i alergii pokarmowej.

Częste zaostrzenia astmy mogą wynikać z:

- niestosowania (lub niepoprawnego stosowania) leczenia $\rightarrow$ kontrola technik inhalacji i compliance (stosowanie się do zaleceń lekarskich)

- współistnienia innych chorób (np. choroby refluksowej, otyłości, przewlekłego nieżytu nosa i zatok, niewydolności serca, zaburzeń psychicznych) $\rightarrow$ optymalizacja leczenia chorób współistniejących

- narażenia na alergeny, dym papierosów lub zanieczyszczenia powietrza $\rightarrow$ eliminacja, gdy nawracające infekcje $\rightarrow$ szczepienia przeciwko grypie i pneumokokom

- ciężkiego przebiegu astmy $\rightarrow$ weryfikacja rozpoznania astmy, eliminacja czynników zaostrzających astmę, sprawdzenie, czy chory rozumie zalecenia lekarskie i czy się do nich stosuje oraz czy potrafi prawidłowo inhalować leki

- problemów natury psychicznej (np. stresu, labilności emocjonalnej) $\rightarrow$ psychoterapia, farmakoterapia.

Zaostrzenia można podzielić na umiarkowane, ciężkie i zagrażające życiu (tab. 1). Umiarkowane zaostrzenie astmy to nasilenie objawów astmy na tyle uciążliwe, że wymaga zmiany dotychczasowego leczenia, ale nie spełnia kryterium ciężkiego zaostrzenia. Natomiast ciężkie zaostrzenie astmy to takie, które wymaga niezwłocznego leczenia, żeby uniknąć hospi- 
talizacji lub zgonu. Poniższa tabela może pomóc w selekcji pacjentów bezwzględnie wymagających oceny stacjonarnej, z uwzględnieniem możliwości danego rodzaju porady zdalnej. Wstępna teleporada pozwala również na selekcję pacjentów wymagających testu w kierunku COVID-19 przed wizytą stacjonarną.

\section{Narzędzia telemedyczne}

Pandemia COVID-19 zmieniła funkcjonowanie wielu obszarów życia, w tym opieki medycznej. Istotne ograniczenie dostępności do placówek ochrony zdrowia oraz personelu medycznego wymusiło wypracowanie nowych metod komunikacji i opieki nad pacjentami. Chorzy na astmę wymagają przewlekłej opieki ukierunkowanej na kontrolę objawów i zapobieganie zaostrzeniom. W przypadku wystąpienia zaostrzenia konieczne mogą być natychmiastowy kontakt z lekarzem prowadzącym i szybka interwencja.

W dostępnej literaturze zwraca się uwagę na przydatność zastosowania technik telemedycznych w opiece nad chorymi na astmę [1]. Były one przedmiotem badań jeszcze przed wybuchem pandemii COVID-19, zanim rozwiązanie to stało się niemal koniecznością. Pandemia nasiliła więc istniejącą już tendencję i niejako wymusiła na pracownikach opieki medycznej i pacjentach zastosowanie nowoczesnych narzędzi telemedycznych.

Należy podkreślić, że telemedycyna jest szerokim pojęciem i może oznaczać zarówno prosty kontakt telefoniczny z chorym, jak i połączenia audio-wideo przez różne ogólnodostępne platformy (np. Skype, ZOOM) oraz przez wyspecjalizowane platformy medyczne (np.: Doximity, San Francisco, California).
Najczęściej teleporady w Polsce pozostają ograniczone do rozmowy audio, w najlepszym przypadku audio-wideo, jednak nie jest to granica możliwości oferowanych przez technologię. Oferta dostępnych urządzeń pozwalających na wykonywanie badań i pomiarów na odległość wciąż rośnie. Do najprostszych należą: termometry, pulsoksymetry oraz ciśnieniomierze, które pozwalają na zapis elektroniczny i przesyłanie wyników przez internet do badającego lekarza. Podobnie dostępne są np.: elektroniczne pikflometry, a nawet miniaturowe, przenośne spirometry pozwalające na wykonywanie pomiarów przepływów oddechowych przez pacjenta w domu lub np. miejscu pracy w czasie odczuwania objawów, zapisywanie wyników i krzywych przepływobjętość w chmurze, które są dostępne dla lekarza prowadzącego, mogącego je w dowolnym czasie zinterpretować. Przykładem wyżej wymienionego urządzenia może być rodzime urządzenie AioCare łączące się ze smartfonem lub z innym urządzeniem mobilnym [2].

Wyszkolony personel pomocniczy (telefacilitator) obecny w miejscu przebywania pacjenta może $\mathrm{w}$ ramach tzw. wizyty ułatwionej (facilitated virtual visit) współpracować z lekarzem przebywającym w innym miejscu, używając elektronicznych narzędzi diagnostycznych, np. elektronicznych stetoskopów nagrywających lub przesyłających bezpośrednio dźwięki do lekarza. W połączeniu z kamerami o wysokiej rozdzielczości można wykorzystać np. dermatoskopy bądź otoskopy. Personel pomocniczy może również wykonywać np. spirometrię, pomiar PEF, wypełnić kwestionariusz kontroli astmy (np. ACT, Asthma Control Test), obsłużyć głowicę ultrasonograficzną.

Tworzone są coraz bardziej złożone systemy i urządzenia integrujące wszystkie wyżej wymienione

Tabela 1. Ocena nasilenia zaostrzenia astmy u dzieci po 6. r.ż., młodzieży $i$ dorostych.

\begin{tabular}{|c|c|c|c|c|}
\hline & \multirow{2}{*}{$\begin{array}{l}\text { MOŻLIWA TELEPORADA } \\
\text { Łagodne/umiarkowane }\end{array}$} & \multicolumn{2}{|c|}{ CHORY WYMAGA OCENY STACJONARNEJ/WEZWANIA POMOCY } \\
\hline & & & Ciężkie & Zagrażające życiu \\
\hline \multirow[b]{2}{*}{ AUDIO } & Porozumiewanie się & Mówi pełnymi zdaniami & Mówi pojedynczymi słowami & Nie jest w stanie rozmawiać \\
\hline & Stan świadomości & Nie jest pobudzony & Pobudzony, niespokojny & $\begin{array}{c}\text { Podsypiający, obecne zaburzenia } \\
\text { świadomości }\end{array}$ \\
\hline \multirow{4}{*}{ WIDEO } & Pozycja ciała & Siedząca & Ortopnoe & Leżąca, półleżąca \\
\hline & Liczba oddechów & $<30 / \mathrm{min}$ & $>30 /$ min & $>30 / \mathrm{min}$ \\
\hline & $\begin{array}{l}\text { Praca dodatkowych miesśni } \\
\text { oddechowych przy oddychaniu }\end{array}$ & Niewidoczna & Widoczna & $\begin{array}{l}\text { Widoczna; mogą być obecne } \\
\text { paradoksalne ruchy oddechowe }\end{array}$ \\
\hline & Sinica & Nie występuje & Może być obecna & Obecna \\
\hline \multirow{4}{*}{$\begin{array}{l}\text { BADANIA } \\
\text { DODATKOWE }\end{array}$} & Obecność zmian osłuchowych & Świsty i furczenia & Świsty i furczenia & „Cicha” klatka piersiowa \\
\hline & Czynność serca & $100-120 / \mathrm{min}$ & $>120 / \mathrm{min}$ & Arytmia \\
\hline & Saturacja & $90-95 \%$ & $<90 \%$ & $<90 \%$ \\
\hline & $\mathrm{PEF}_{\mathrm{akk}} / \mathrm{PEF}_{\max }$ & $>50 \%$ & $\leq 50 \%$ & $<30 \%$ \\
\hline
\end{tabular}

$\mathrm{PEF}_{\text {akt }}$ - aktualny szczytowy przepływ wydechowy; $\mathrm{PEF}_{\max }$ - maksymalny szczytowy przepływ wydechowy. 
urządzenia i przesyłające wyniki lekarzowi do interpretacji. Przykładem może być opracowywana platforma Higo - aplikacja pozwalająca na zebranie wywiadu medycznego; zintegrowane z nią urządzenie jest wyposażone w termometr, kamerę umożliwiającą obrazowanie skóry, ucha i gardła oraz stetoskop.

Interwencje telemedyczne opisywane w literaturze bywają skrajnie różne, stąd porównywanie danych lub wyciąganie jednoznacznych wniosków dotyczących skuteczności telemedycyny w opiece nad chorymi na astmę jest trudne. Według metaanalizy autorstwa Chongmelaxme i wsp., w której porównywano dane dotyczące jakości życia i kontroli astmy w różnych krajach (zarówno rozwiniętych, jak i rozwijających się), opieka nad pacjentami z astmą przy użyciu technik telemedycznych poprawiała zarówno kontrolę astmy, jak i jakość życia pacjentów [1]. Przydatność i bezpieczeństwo wizyt telemedycznych jest różna w okresie stabilnym astmy czy jej zaostrzeniu.

Wizyty telemedyczne u chorych na astmę moga służyć przede wszystkim:

- edukacji pacjentów na temat ich choroby i zasad leczenia

- ustaleniu stosowania się do zaleceń lekarskich, m.in. powtórzeniu informacji o istotności zaprzestania palenia, wyeliminowania alergenów, unikania infekcji, w tym edukacji dotyczącej szczepień, stosowania leków przeciwzapalnych

- ocenie kontroli astmy oraz czynników ryzyka zaostrzeń: kwestionariusze kontroli astmy, np. ACT, pomiary PEF, pytania o compliance, zużycie krótko działających $\beta_{2}$-mimetyków, kontrolę objawów chorób współistniejących itd.

- kontroli i poprawie techniki inhalacji: optymalnie podczas wizyty z wykorzystaniem wideo, chociaż możliwe jest przeprowadzenie kontroli poprzez poproszenie chorego o opisanie czynności wykonywanych podczas inhalacji

- modyfikacji dotychczasowego leczenia w zależności od kontroli astmy: optymalnie na podstawie mierzalnych, obiektywnych wskaźników, jak samodzielne pomiary PEF, kwestionariusze kontroli astmy, np. ACT.

W tym kontekście wizyty telemedyczne mają wiele udowodnionych zalet - takich jak wysoka satysfakcja pacjentów (nawet 98,8\%), oszczędność czasu i kosztów podróży, zmniejszenie liczby dni absencji w pracy i szkole [3]. Podobne wnioski płyną z badania z USA już z okresu pandemii COVID-19, w którym
97\% pacjentów było usatysfakcjonowanych telewizytą, a 77,4\% uczestników podało, że wizyta w ich opinii była równie satysfakcjonująca, jak stacjonarna [4].

Co więcej, dzięki rozpowszechnieniu sieci telekomunikacyjnej (telefon, internet) interwencje telemedyczne pozwalają na objęcie opieką pacjentów w miejscach oddalonych od ośrodków miejskich, w rejonach o dużym rozproszeniu ludności [5].

Niestety, telemedycyna nie jest rozwiązaniem idealnym. Wciąż istotnym problemem pozostaje tzw. wykluczenie cyfrowe - według CBOS blisko połowa Polaków w wieku 55-64 lata i trzy czwarte w wieku 65 lat i więcej w ogóle nie korzysta $z$ internetu [6]. Dostęp do telefonu w Polsce nie jest problemem, jednak brak dostępu do internetu znacząco ogranicza możliwości telemedycyny. Co więcej, telemedycyna może być niewystarczająca do ustalania rozpoznania astmy, ale przede wszystkim nie jest właściwą metodą opieki nad pacjentem niestabilnym, wykazującym objawy ostrego zaostrzenia choroby. Teleporada może za to pełnić doskonale funkcję wizyty kontrolnej po zaostrzeniu.

Pandemia COVID-19 znacząco utrudniła dostęp pacjentów do lekarzy wszystkich specjalności. Zagrożenie epidemiczne zniechęca również pacjentów do wizyt stacjonarnych, zwłaszcza w grupie osób obciążonych chorobami płuc i osób starszych. Zmiany te znacząco zwiększyły zastosowanie teleporad u pacjentów z astmą w Polsce i na świecie, które pomimo swoich ograniczeń jednak zwiększają możliwość dostępu do profesjonalistów opieki medycznej. W praktyce większość tych wizyt ma charakter dwustronnych rozmów telefonicznych lub czatu. Główną rolą lekarza pełniącego opiekę nad pacjentem z astmą jest utrzymanie lub poprawa kontroli choroby, rozpoznanie zaostrzenia i odróżnienie zaostrzeń łagodnych (które można leczyć w domu) od stanów wymagających interwencji bezpośredniej - wizyty stacjonarnej, wizyty na SOR bądź wezwania pogotowia.

Poniżej przedstawiamy elementy wizyty lekarskiej w ujęciu teleopieki nad pacjentami z astmą.

Warto pracować na przygotowanych wcześniej szablonach, aby uniknąć pominięcia ważnych aspektów wywiadu, m.in. narażenia na alergeny, dym tytoniowy, inne zanieczyszczenia powietrza, objawy choroby refluksowej przełyku czy przewlekłego zapalenia zatok obocznych nosa, niedostateczny compliance.

Poniżej zaproponowano przykładowy szablon do badania podmiotowego możliwego do wykorzystania podczas teleporady chorego na astmę: 
WIZYTA KONTROLNA/WIZYTA Z POWODU

NASILENIA OBJAWÓW (wybierz właściwe)

- Jeśli objawy, jakie? ...

- Aktualny PEF:

- Czy w ostatnim miesiącu objawy astmy występowały częściej niż 2 razy w tygodniu? TAK/NIE

- Czy w ostatnim miesiącu występowały jakiekolwiek objawy nocne lub poranne? TAK/NIE

- Czy w ostatnim miesiącu konieczne było zastosowanie leków doraźnych częściej niż 2 razy w tygodniu? TAK/NIE

- $\mathrm{Czy}$ w ostatnim miesiącu z powodu astmy wystąpiło jakiekolwiek ograniczenie aktywności? TAK/NIE

KONTROLA ASTMY: DOBRA (wszystkie NIE)/ CZĘ́SCIOWA (1-2 TAK)/BRAK (> 2 TAK)

- Czy od ostatniej wizyty wystapiło zaostrzenie wymagające modyfikacji terapii?

- Jeśli tak, kiedy? ...; zastosowane leczenie? ... glikokortykosteroid systemowy? TAK/NIE, dawka ...

- Wpływ czynników zewnętrznych na objawy? TAK/ NIE

jakie? ...

- Palenie tytoniu? TAK/NIE / bierne narażenie na dymy? TAK/NIE

- Objawy spływania wydzieliny po tylnej ścianie gardła? TAK/NIE

- Zgaga / pieczenie w przełyku / cofanie się treści pokarmowej? TAK/NIE; czy stosuje IPP? TAK/NIE

- Regularne stosowanie leków wziewnych? TAK/NIE Jakie leczenie na stałe? ...

- Zgłaszane problemy z zastosowaniem inhalatora? TAK/NIE

jakie? ...

- Zalecenia:...

\section{Badanie przedmiotowe w czasie teleporady}

Teleporada ze względu na dystans do pacjenta znacząco ogranicza możliwości badania przedmiotowego, jednak całkowicie go nie uniemożliwia. Należy pamiętać, że podstawowym i pierwszym elementem badania przedmiotowego pozostaje oglądanie pacjenta, a ogólne wrażenie bywa wystarczające do oceny, czy chory jest w dobrym stanie. Przede wszystkim powinno się zwrócić uwagę na wskaźniki nasilonego wysiłku oddechowego.

Oglądając, możemy stwierdzić (porada wideo):

- częstość oddechów

- poruszanie się skrzydełek nosa

- zapadanie się międzyżebrzy/dołków nadobojczykowych
- zaangażowanie dodatkowych mięśni oddechowych

- bladość lub sinicę.

Słuchając (przez słuchawkę telefonu/głośnik, bez stetoskopu), możemy stwierdzić (audio-wideo lub tylko audio):

- mówienie niepełnymi zdaniami

- wydłużoną fazę wydechu

- świsty oddechowe - bywają słyszalne bez użycia stetoskopu

- nasilenie kaszlu

- częstość oddechów.

Bardzo przydatnym narzędziem w ocenie ciężkości zaostrzenia podczas teleporady będzie pulsoksymetr, który pozwoli ocenić nie tylko wysycenie krwi tętniczej tlenem, ale również czynność serca. Warto, wykorzystując coraz większą dostępność do pulsoksymetrów, wyposażać w to urządzenie chorych na astmę.

Już tak ograniczona ocena może być wystarczająca do decyzji o konieczności wizyty stacjonarnej (domowej) lub wezwaniu zespołu pogotowia ratunkowego.

\section{Ocena kontroli astmy}

Znanym i uznanym narzędziem do oceny stopnia kontroli astmy jest uproszczony test ACT. Cztery proste pytania dotyczące objawów występujących w ciągu poprzedzających 4 tygodni powinny być elementem każdej wizyty kontrolnej chorego na astmę:

- Czy objawy astmy występowały częściej niż 2 razy w tygodniu?

- Czy występowały jakiekolwiek objawy nocne lub poranne?

- Czy konieczne było zastosowanie leków doraźnych częściej niż 2 razy w tygodniu?

- Czy z powodu astmy wystąpiło jakiekolwiek ograniczenie aktywności?

Zaprzeczenie we wszystkich odpowiedziach wskazuje na astmę dobrze kontrolowaną, jedna lub dwie odpowiedzi twierdzące - na astmę częściowo kontrolowaną; przy wykazaniu ponad dwóch odpowiedzi twierdzących astma jest niekontrolowana, a pacjent wymaga szczególnie starannej oceny i intensyfikacji leczenia.

Test ACT można wypełniać wspólnie z chorym podczas telewizyty, jednak istnieją również aplikacje, za których pomocą pacjent samodzielnie zaznacza odpowiedzi, a personel medyczny może je zdalnie monitorować. W przypadku astmy niekontrolowanej pacjent 
wymaga szczególnego nadzoru, identyfikacji przyczyny braku kontroli, optymalnie kontroli w krótkim okresie.

\section{Pomiar szczytowego przepływu wydechowego}

$\mathrm{W}$ monitorowaniu astmy przydatny $\mathrm{w}$ przewidywaniu jej zaostrzenia jest pomiar PEF, który pacjent może samodzielnie wykonywać w domu. PEF to maksymalna prędkość przepływu powietrza, jaką można uzyskać podczas wydechu. Badanie jest szybkie i łatwe do przeprowadzenia, nawet $\mathrm{u}$ dzieci. Do jego wykonania potrzebny jest miernik PEF, tzw. pikflometr (na rynku dostępne są przyrządy analogowe lub elektroniczne). Po wykonaniu trzech pomiarów pacjent zapisuje najlepszy wynik. Za pomocą pikflometru powinny zostać oznaczone dwie wartości:

- $\mathrm{PEF}_{\max }$ - najlepszy PEF, kiedy chory czuje się bardzo dobrze i od dłuższego czasu nie miał objawów choroby ani w dzień, ani w nocy - to jest najlepszy wynik osobisty konkretnego pacjenta

- zmienność PEF (zmienność dobowa lub w dłuższym okresie) - obliczona na podstawie odczy-

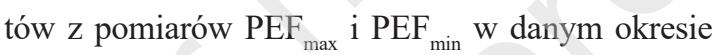
według poniższego wzoru:

Zmienność dobowa PEF $=\left[\left(\mathrm{PEF}_{\max }-\mathrm{PEF}_{\min }\right):\left(\mathrm{PEF}_{\max }+\right.\right.$ $\left.\left.\mathrm{PEF}_{\min } / 2\right)\right] \times 100 \%$

Przy dwóch pomiarach w ciągu doby za prawidłową zmienność dobową uznaje się występowanie różnicy mniejszej niż 10\% u dorosłych i 13\% u dzieci. W ocenie zmienności dziennej bierze się pod uwagę najwyższą i najniższą wartość PEF w danym dniu, a w przypadku zmienności w dłuższym czasie - najbardziej skrajne wartości w danym okresie [7].

\section{Pomoc w zaprzestaniu palenia}

Czas teleporady najczęściej jest ograniczony, warto jednak zapytać o nałóg palenia tytoniu. Nikotynizm poza znanymi niekorzystnymi działaniami, jak zwiększone ryzyko zachorowania na wiele nowotworów i zwiększone ryzyko sercowo-naczyniowe, u chorych na astmę dodatkowo zwiększa ryzyko zaostrzeń i może doprowadzić do utrwalenia obturacji czy wręcz rozwinięcia się przewlekłej obturacyjnej choroby płuc (POChP). Zalecana jest tzw. interwencja minimalna ,,5 × P” (pytaj, poradź, pamiętaj, pomagaj, planuj), jednak nawet ta minimalna interwencja wymaga czasu całej wizyty. Warto jednak zachęcać chorych do rzucania palenia przy każdej okazji i skierować ich np. do Telefonicznej Poradni Pomocy Palącym (tel. 801108 108, 2221180 15, a także przekazywać wiarygodne materiały, np. w formie przesłanego linku: jakrzucicpalenie.pl.

\section{Zapewnienie pisemnego planu postępowania}

Pisemny plan postępowania jest zalecany w rekomendacjach dotyczących opieki nad chorymi na astmę. Wyposażenie pacjenta w taki plan ma poprawić skuteczność radzenia sobie z nasilonymi objawami czy zaostrzeniem i powinien on zawierać informacje na temat:

- zwiększenia dawek leków kontrolujących i doraźnych w przypadku nasilenia objawów

- krótkiej wstawki z systemowych GKS, gdy wystąipi ciężkie zaostrzenie

- $\quad$ sytuacji, w których należy szukać pomocy medycznej.

Poniżej zamieszczamy przykładowy pisemny plan leczenia astmy, w który należy wyposażyć chorego.

\section{PLAN POSTĘPOWANIA W ASTMIE}

Dane pacjenta ... Data ... $\mathrm{PEF}_{\text {max }} \ldots$

Stałe leki przeciwastmatyczne: ....

Lek doraźny w razie napadu astmy: ...

\section{DOBRA KONTROLA ASTMY, jeśli:}

- Nie ma napadów duszności, świstów, napadów kaszlu.

- Tolerancja wysiłku jest dobra, można wykonywać wszystkie czynności fizyczne.

- $\quad$ PEF powyżej $80 \% \mathrm{PEF}_{\max }, \mathrm{tj} .>$...

UMIARKOWANE ZAOSTRZENIE ASTMY, jeśli:

- Występują napady duszności, kaszlu, ucisk w klatce piersiowej $>2$ razy w tygodniu.

- $\mathrm{Z}$ powodu duszności pogorszyła się tolerancja wysiłku, pojawiły się trudności w wykonywaniu wysiłku fizycznego.

- $\quad$ PEF $50-79 \% \mathrm{PEF}_{\max }$, tj. od ... do ...

\section{POSTĘPOWANIE:}

- Zastosuj stałe leki oraz dodatkowo ... 2 wdechy co 20-30 min przez godzinę.

- Jeśli brak poprawy, weź stałe leki oraz ... 2 wdechy co 4-6 h.

- ...mg dziennie przez ... dni.

- Skontaktuj się z lekarzem w ciągu 12 h od przyjęcia glikokortykosteroidów systemowych.

- Telefon do lekarza ...

\section{CIĘŻKIE ZAOSTRZENIE ASTMY, jeśli:}

- wystąpiła silna lub bardzo silna duszność mimo leczenia lub

- brak poprawy po lekach doraźnych, lub

- objawy astmy nasilają się w ciągu 24 h mimo intensyfikacji leczenia 
- $\quad \mathrm{PEF}<50 \% \mathrm{PEF}_{\max }$, tj. poniżej ...

\section{POSTĘPOWANIE:}

- Zastosuj: ... 4-8 wdechów.

- Zastosuj jednorazowo 40 mg* prednizonu doustnie.

- Wezwij pogotowie lub zgłoś się jak najszybciej do szpitala, jeśli brak poprawy po 15-20 min lub nie udało się skontaktować z lekarzem.

Tabela 2. Wady i zalety teleporad.

\begin{tabular}{|c|c|}
\hline Zalety & Wady \\
\hline Brak kosztów i czasu dojazdu & $\begin{array}{l}\text { Ograniczona możliwość bada- } \\
\text { nia przedmiotowego }\end{array}$ \\
\hline $\begin{array}{l}\text { Dostęp do opieki medycznej dla } \\
\text { pacjentów z rejonów o dużym rozpro- } \\
\text { szeniu ludności }\end{array}$ & $\begin{array}{l}\text { Ograniczona możliwość wyko- } \\
\text { nania badań przyrządowych }\end{array}$ \\
\hline Oszczędność czasu pacjenta & $\begin{array}{l}\text { Brak osobistego kontaktu } \\
\text { - utrudnienie w nawiązaniu } \\
\text { relacji z pacjentem }\end{array}$ \\
\hline $\begin{array}{l}\text { Bezpieczeństwo epidemiczne - zarów- } \\
\text { no dla personelu, jak i pacjenta }\end{array}$ & $\begin{array}{l}\text { Niepełna możliwość oceny } \\
\text { techniki inhalacji (A) }\end{array}$ \\
\hline $\begin{array}{l}\text { Łatwy dostęp dla pacjentów } \\
\text { o mniejszych możliwościach porusza- } \\
\text { nia się, np. niepełnosprawnych, bez } \\
\text { środka transportu }\end{array}$ & $\begin{array}{l}\text { Brak możliwości podania leków } \\
\text { interwencyjnie }\end{array}$ \\
\hline $\begin{array}{l}\text { Elastyczność organizacyjna opieki } \\
\text { medycznej - możliwość obsługi } \\
\text { pacjentów z dowolnego obszaru }\end{array}$ & $\begin{array}{l}\text { Trudności w obsłudze internetu } \\
\text { i urząazeń komunikacyjnych } \\
\text { przez niektórych chorych }\end{array}$ \\
\hline $\begin{array}{l}\text { Możliwość utrzymania opieki w okre- } \\
\text { sach ograniczeń epidemicznych }\end{array}$ & $\begin{array}{l}\text { Nowe doświadczenie dla } \\
\text { personelu medycznego }\end{array}$ \\
\hline $\begin{array}{l}\text { Możliwość uzyskania porady przed } \\
\text { otrzymaniem wyniku testu COVID-19 } \\
\text { lub w trakcie kwarantanny/izolacji }\end{array}$ & \\
\hline
\end{tabular}

A - dotyczy teleporad wyłącznie audio.

\section{Podsumowanie}

Wykorzystanie technologii cyfrowej, telemedycyny i telezdrowia w monitorowaniu chorych na astmę gwałtownie wzrasta, szczególnie podczas pandemii COVID-19. Jednak rodzaje interakcji są zróżnicowane, więc ocena ich użyteczności i skuteczności wymaga wysokiej jakości badań. Powodzenie ich zastosowania zależy od jakości wcześniejszej opieki nad chorym oraz od przebiegu astmy.

\footnotetext{
* Dawka w przypadku osoby dorosłej.
}

\section{Piśmiennictwo}

1. Chongmelaxme B, Lee S, Dhippayom T et al. The Effects of Telemedicine on Asthma Control and Patients' Quality of Life in Adults: A Systematic Review and Meta-analysis. J Allergy Clin Immunol Pract. 2019; 7(1): 199-216.el1.

2. Jankowski P, Górska K, Mycroft K et al. The use of a mobile spirometry with a feedback quality assessment in primary care setting - A nationwide cross-sectional feasibility study. Respir Med. 2021; 184: 106472.

3. Waibel KH, Bickel RA, Brown T. Outcomes From a Regional Synchronous Tele-Allergy Service. J Allergy Clin Immunol Pract. 2019; 7(3): 1017-21.

4. Mustafa SS, Yang L, Mortezavi M. Patient satisfaction with telemedicine encounters in an allergy and immunology practice during the coronavirus disease 2019 pandemic. Ann Allergy Asthma Immunol. 2020; 125(4): 478-9.

5. Brown W, Odenthal D. The uses of telemedicine to improve asthma control. J Allergy Clin Immunol Pract. 2015; 3(2): 300-1.

6. Badanie CBOS „Korzystanie z Internetu” z maja 2018. https://www.cbos.pl/SPISKOM.POL/2020/K_085_20.PDF.

7. Global Initiative for Asthma (GINA). Global Strategy for Asthma Management and Prevention. www.ginasthma.org (access: 17.11.2021).

ORCID

K. Górska - ID - http://orcid.org/0000-0003-4686-910X

M. Mierzejewski - ID - http://orcid.org/0000-0001-7867-170X

Wkład autorów/Authors' contributions:

K. Górska: 50\%; M. Mierzejewski: 50\%.

Konflikt interesów/Conflict of interests:

Nie występuje.

Finansowanie/Financial support:

Nie występuje.

Etyka/Ethics:

Treści przedstawione w artykule są zgodne z zasadami Deklaracji Helsińskiej, dyrektywami EU oraz ujednoliconymi wymaganiami dla czasopism biomedycznych.

Copyright: @ Medical Education sp. z 0.0. This is an Open Access article distributed under the terms of the Attribution-NonCommercial 4.0 International (CC BY-NC 4.0). License (https://creativecommons.org/licenses/by-nc/4.0/), allowing third parties to copy and redistribute the material in any medium or format and to remix, transform, and build upon the material, provided the original work is properly cited and states its license.

Adres do korespondencji

dr hab. n. med. Katarzyna Górska

Katedra i Klinika Chorób Wewnętrznych Pneumonologii i Alergologii, Warszawski Uniwersytet Medyczny 02-097 Warszawa, ul. Banacha 1A e-mail: drkpgorska@gmail.com 